\title{
CARA HALAL MEMILIKI HARTA
}

\author{
Oleh: Dra. Hj.Tjek Tanti, Lc, M.A \\ tjektanti@gmail.com \\ Dosen Fakultas Syariah dan Hukum UIN Sumatera Utara
}

\begin{abstract}
Humans need wealth in meeting their needs. Property is a basic human need, both for clothing, food and shelter. With wealth someone supports himself, his family and also his religion. Therefore humans always look for it and try to get it. Treasure can provide happiness in this world and the hereafter if it is obtained from halal sources and used in the right things. But on the contrary property will be disastrous if obtained in the wrong way and used for bad things. Therefore, in obtaining the wealth of Muslims it is necessary to know the principles and norms in Islamic Law about how to obtain halal property. The following article discusses various matters relating to the halal way of owning assets.
\end{abstract}

Keyword : Halal, Milk, Harta

\section{A. PENDAHULUAN}

Fenomena ketidakpedulian manusia terhadap sumber harta sudah nampak nyata dalam kehidupan sehari-hari. Hal ini persis seperti apa yang telah disampaikan Rasulullah 14 abad yang lalu yaitu :

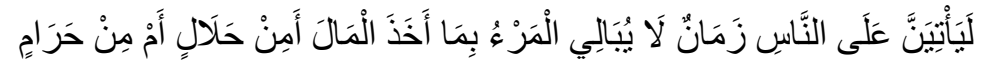

Artinya: akan datang suatu masa pada umat manusia dimana mereka tidak lagi perduli dari mana ia mendapatkan harta, apakah dari yang halal ataukah dari yang haram. (HR. Bukhari).

Rasulullah SAW telah memberi peringatan kepada orang yang memakan harta haram, dalam sabda beliau:



Artinya: sesungguhnya tidak masuk surga daging yang tumbuh dari harta yang haram. Neraka lebih pantas untuknya (HR. Ahmad dan Ad-Darimi).

Rasulullah juga sangat menekankan agar umatnya mencari harta yang halal, dan membelanjakannya juga untuk hal-hal yang baik. Pertanggungjawaban manusia terhadap harta mencakup dua sisi, dari mana didapat dan kemana pula harta tersebut dihabiskan.

Berita tentang penipuan, pencurian, perampokan, pembegalan yang hampir setiap hari kita baca di koran atau kita lihat di tv, bahkan yang terjadi di sekitar kita, merupakan bukti nyata ketidakpedulian orang terhadap sumber hartanya. Terlebih, ketidakpedulian ini muncul di tengah-tengah para hartawan, orang yang sudah berkecukupan dan hidup mewah. Lebih parahnya lagi, kasus korupsi dikalangan pejabat dan orang-orang terhormat di negeri ini sudah begitu mewabah. Ibarat penyakit, para dokter sudah kewalahan. Entah vaksin apa lagi yang harus disuntikkan.

Korupsi adalah praktik mendapatkan harta secara bathil dan sudah dipastikan merupakan perkara yang diharamkan dalam Islam. Merebaknya wabah korupsi ini dapat dikaitkan dengan ketidakpedulian orang akan asal usul atau sumber hartanya. Fenomena ketidakpedulian masyarakat pada umumnya terhadap sumber harta dan kekayaan ini boleh jadi disebabkan karena mereka tidak tahu tentang fungsi dan kedudukan harta yang harus ia jaga dengan baik. Boleh jadi juga karena tidak mengerti adanya pertanggungjawaban manusia 
terhadap hartanya kelak, tidak tahu adanya harta halal dan harta haram atau memang tidak mau tahu dengan semua itu yang penting aku punya harta. Dengan menutup mata, anggap saja semua terjadi karena ketidaktahuan sama sekali tentang hal itu. Karenanya, harus ada penjelasan tentang semua seluk beluk harta tersebut agar terhindar dari dosa yang kelak bisa jadi penyesalan.

\section{B. PENGERTIAN HARTA}

Secara bahasa, harta yang dalam kajian fiqh Islam khususnya fiqh Muamalah disebut mal (مال) yang berarti condong, cenderung dan miring. Penggunaan kata mal sebab manusia selalu cenderung kepadanya, bahkan sangat suka kepada mal ini. Allah Swt menyatakan tentang kecondongan hati manusia terhadap harta ini dalam firmanNya:



Artinya: "Dan kamu mencintai harta benda dengan kecintaan yang berlebihan".

Secara istilah harta didefinisikan oleh para ulama fiqh sebagai berikut: Pertama, definisi yang dikemukakan ulama Hanafiyah:

ما يميل اليه طيع الإنسان ويمكن ادخاره الى وقت الحاجة, اوكان ما يمكن حيازته و أحر ازه وينتفع به عادة.

"Harta adalah segala sesuatu yang diminati manusia dan dapat dihadirkan ketika diperlukan, Atau segala sesuatu yang dapat dikuasai, disimpan dan dimanfaatkan menurut biasanya".

Dalam definisi ini tersirat bahwa manfaat tidak termasuk harta walaupun menurut mereka manfaat termasuk milik.

Kedua, definisi jumhur ulama selain ulama Hanafiyah:

$$
\text { كل ما له قيمة بلزم متلفها بضمانه. }
$$

"Harta adalah segala sesuatu yang mempunyai nilai dan dikenakan ganti rugi bagi orang yang merusak atau melenyapkannya".

Dalam kandungan kedua definisi di atas, terdapat perbedaan esensi harta yang dikemukakan jumhur dengan ulama Hanafiyah. Menurut jumhur ulama, harta itu mencakup yang bersifat materi dan juga manfaat suatu benda. Sementara ulama Hanafiyah berpendirian bahwa harta itu hanya yang bersifat materi saja sedangkan manfaat bukan harta tapi masuk dalam pengertian milik.

Dari kedua definisi di atas dapat disimpulkan bahwa harta adalah segala sesuatu yang disukai manusia, dapat dikuasai, dapat disimpan dan dapat dimanfaatkan menurut biasanya dan orang yang merusaknya dapat dituntut ganti rugi. Oleh sebab itu sesuatu yang tidak disukai manusia bukanlah harta seperti kotoran dan racun, juga bukan namanya harta sesuatu yang tidak mungkin dikuasai seperti udara, sinar matahari dan cahaya bulan, juga yang tidak bisa disimpan seperti kemuliaan dan kesehatan, juga yang tidak mungkin dimanfaatkan seperti sebutir beras atau setitik air.

\section{KEDUDUKAN HARTA}

Harta merupakan kebutuhan penting manusia dalam menjalani kehidupan di dunia ini sehingga para ulama ushul fiqh memasukkannya dalam salah satu ad-dharuriyah al$k_{\text {kamsah }}^{4}$ (lima kebutuhan pokok) yang harus dipelihara yaitu: agama, jiwa, akal, keturunan dan harta. Dalam Alquran Allah SWT menyebutkan bahwa harta mempunyai kedudukan antara lain:

\footnotetext{
${ }^{1}$ Departemen Agama, Alquran dan Terjemahnya, (Jakarta: Sabiq, 2009), h. 593.

${ }^{2}$ Ibn Abidin, Radd al-Muhtar 'ala ad-Darr al-Mukhtar, Jilid IV, (Beirut: Dar al-Fikri, tth), h. 3.

${ }^{3}$ Jalaluddin Abdurrahman as-Suyuthi, al-Ashbah wa an-Nazhair, (Singapura: Sulaiman Mar'i, tth), h. 258. Lihat juga Wahbah Zuhailiy, al-Fiqh al-Islamiy wa Adillatuhu, Juz IV, (Damaskus: Dar al-Fikr, 1997), h.2
} 
1. Harta Sebagai Perhiasan Hidup

Manusia mempunyai kecenderungan yang kuat untuk memiliki harta sebanyakbanyaknya dengan anggapan tatkala ia memiliki harta yang cukup, ia dapat memenuhi kebutuhan hidupnya dan dapat pula mencapai keinginan serta cita-citanya. Ia dapat menikmati hidup dengan lebih baik dibandingkan dengan orang yang kekurangan harta, dengan harta hidup ini begitu indah. Allah SWT berfirman:





Artinya: "Dijadikan indah pada (pandangan) manusia kecintaan kepada apa-apa yang diingini, Yaitu: wanita-wanita, anak-anak, harta yang banyak dari jenis emas, perak, kuda pilihan, binatang-binatang ternak dan sawah ladang. Itulah kesenangan hidup di dunia, dan di sisi Allah-lah tempat kembali yang baik (surga)" (QS. Ali Imran:14). ${ }^{5}$

Pada ayat lain Allah berfirman:



Artinya: "Harta dan anak-anak adalah perhiasan kehidupan dunia tetapi amalanamalan yang kekal lagi saleh adalah lebih baik pahalanya di sisi Tuhanmu serta lebih baik untuk menjadi harapan" (QS. Al-Kahfi: 46). ${ }^{6}$

2. Harta Sebagai Amanah/titipan dari Allah SWT

Allah SWT mengamanahkan kepada manusia untuk mengelola dan memanfaatkan harta sesuai dengan ketentuanNya. Pemilik sebenarnya dari harta yang dimiliki manusia adalah Allah SWT. Sebagaimana firmanNya:



Artinya: "Berimanlah kamu kepada Allah dan Rasul-Nya dan nafkahkanlah sebagian dari hartamu yang Allah telah menjadikan kamu menguasainya. Maka orang-orang yang beriman di antara kamu dan menafkahkan (sebagian) dari hartanya memperoleh pahala yang besar" (QS. Al-Hadid: 7). ${ }^{7}$

Islam tidak melarang seseorang untuk mencari kekayaan sebanyak-banyaknya asal tidak melanggar prinsip umum yang berlaku, yaitu halal dan baik. Disamping pemanfaatan harta untuk diri sendiri, keluarga, dan orang-orang dibawah tanggung jawabnya, sebahagian harta tersebut juga diinfakkan untuk orang lain yang membutuhkan bantuan seperti fakir, miskin, anak yatim dan juga untuk kepentingan agama Islam. Dalam ayat di atas Allah memerintahkan manusia untuk menafkahkan sebagian harta yang telah dikuasakannya kepada manusia sebagai pemiliknya. Namun, kecintaan manusia yang berlebihan terhadap harta membuatnya menjadi tamak, rakus, serakah dan bakhil. Hanya orang-orang berimanlah yang mau menafkahkan sebagian hartanya untuk mendapatkan pahala dan ridha dari Allah SWT.

3. Harta Sebagai Ujian Keimanan

Allah berfirman:



Artinya: "Sesungguhnya hartamu dan anak-anakmu hanyalah cobaan (bagimu), dan di sisi Allah-lah pahala yang besar" (QS. At-Taghaabun: 15). ${ }^{8}$

Seringkali orang yang Allah titipkan kepadanya harta yang banyak malah menjadi lupa bersyukur. Jangankan untuk berinfak, berzakat sebagai bentuk kewajibannya saja ia berfikir seribu kali. Terkadang, orangtuanya sendiri pun tidak diberinya nafkah. Ia merasa khawatir kalau hartanya berkurang. Malah, hartanya dihabiskan untuk berfoya-foya. Harta

\footnotetext{
${ }^{5}$ Departemen Agama, Alquran dan Terjemahnya, h. 51.

${ }^{6}$ Ibid., h. 299.

${ }^{7}$ Ibid., h. 538 .

${ }^{8}$ Ibid., h. 557.
} 
yang banyak bukan membuat diri makin dekat dengan sang Pemberi, bahkan ia telah membeli murkaNya.

Alquran mengingatkan manusia bahwa harta dan anak yang dibanggakan tidak menjamin dapat menyelamatkan dirinya dari siksa Allah. Terkadang sifat berbangga yang berlebihan melahirkan sifat kikir serta suka mengumpulkan harta dengan sangat perhitungan. Tanpa sadar liang kubur pun sudah menantinya. Allah berfirman:



Artinya: "Bermegah-megahan telah melalaikan kamu. Sampai kamu masuk ke dalam kubur" (QS. At-Takaatsur: 1-2). ${ }^{9}$

Sungguh manusia lupa bahwa harta yang ia kumpulkan dan cari mati-matian harus dipertanggungjawabkan kelak dihadapan Allah SWT.

\section{MANFAAT DAN FUNGSI HARTA}

Pada hakikatnya, harta yang Allah berikan kepada manusia bertujuan untuk memaksimalkan tujuan penciptaan manusia itu sendiri, yaitu untuk mengabdi kepadaNya. Allah berfirman “



Artinya: "Dan Aku tidak menciptakan jin dan manusia melainkan supaya mereka mengabdi kepada-Ku” (QS. Adz-Dzariyat: 56). ${ }^{10}$

Harta ibarat pisau bermata dua. Harta dapat dipakai untuk membangun, memperindah, memperbaiki, menggembirakan, mengakrabkan dan banyak hal-hal positif lainnya. Sebaliknya, harta juga dapat merobohkan, merusak, menyengsarakan, memutuskan hubungan kerabat, pembunuhan, fitnah dan berbagai keburukan. Manusia yang menyadari hakikat harta maka ia tidak akan menjadi budak dan hamba harta, tetapi ia akan menggunakannya sebagai ibadah secara langsung maupun tidak langsung.

Beberapa manfaat dan fungsi harta yang diberikan Allah kepada manusia sebagai amanah yang harus dijaga yaitu:

1. Untuk memenuhi kebutuhan hidup manusia

Allah adalah pemilik mutlak alam semesta. Manusia diberikan amanah untuk mengelola harta yang diberikan untuk memenuhi kebutuhan hidup sebagaimana termaktub pada QS. Al-Hadid ayat 7 diatas. Penguasaan harta dalam ayat tersebut tentu bukan secara mutlak karena hak milik mutlak hanya Allah SWT. Manusia hanya boleh memanfaatkan harta sesuai ketetapanNya.

2. Untuk bekal ibadah (menyempurnakan pelaksanaan ibadah)

Apapun ibadah yang dilakukan manusia dalam mengabdi kepada Allah tentu memerlukan harta. Untuk shalat manusia perlu menutup aurat, untuk shalat berjamaah perlu sarana mushalla atau mesjid, untuk berpuasa perlu pula bersahur dan berbuka dengan makanan dan minuman, untuk dapat melaksanakan ibadah haji tentu memerlukan lebih banyak lagi harta. Begitu juga untuk bersedekah, membantu para dhuafa', dan korban bencana alam, semuanya memerlukan harta. Singkatnya, harta sangat dibutuhkan untuk menopang pelaksanaan ibadah, baik langsung maupun tidak.

3. Untuk menuntut ilmu

Dalam menuntut ilmu, harta sangat diperlukan bagi manusia, terlebih sebagai upaya memperdalam ilmu-ilmu agama. Harta digunakan untuk membeli buku dan alat-alat pelajaran, biaya transportasi dan lain sebagainya. Tanpa harta, tentu seseorang akan merasa sulit untuk meneruskan pendidikannya dari satu jenjang ke jenjang yang lebih tinggi.

\footnotetext{
${ }^{9}$ Ibid., h. 600 .

${ }^{10}$ Ibid., h. 523.
} 
Terkadang, seseorang harus keluar dari kampung halamannya untuk menuntut ilmu dan harta pasti dibutuhkan dalam hal tersebut.

4. Untuk meningkatkan keimanan dan ketakwaan

Keimanan dan ketakwaan seseorang dikatakan dapat naik dan turun berdasarkan sabda nabi. Hal tersebut tidak terlepas dari faktor kondisi atau keadaan harta yang ia miliki. Keadaan fakir pada seseorang dapat mendekatkan dirinya kepada kekufuran, sebagaimana sabda Rasulullah SAW:

$$
\text { كادَ الَفَرْرُ أَنْ يَكُوْنَ كُفْرًا }
$$

Artinya:"Hampir-hampir kefakiran (kemiskinan) itu membuat seseorang menjadi kafir" (HR. Baihaqi).

5. Untuk menumbuhkan dan menguatkan silaturrahim

Dengan harta, seseorang mampu menjaga jalinan silaturrahim semakin baik dan erat. Saling memberi hadiah atau membawa buah tangan dan berkunjung ke rumah saudara atau sahabat menjadi salah satu fungsi harta yang dimiliki manusia. Dengan saling memberi, maka ikatan persaudaraan maupun persahabatan akan semakin kuat, sembari menumbuhkan cinta dan kasih sayang diantara sesama manusia. Nabi bersabda:



Artinya: "saling memberi hadiahlah kalian, maka kalian akan saling mencintai".

6. Untuk menegakkan agama Allah

Menegakkan agama tentu merupakan kewajiban setiap muslim. Agar agama dapat ditegakkan diperlukan biaya, mulai dari mengadakan penyuluhan agama kepada masyarakat, mendirikan madrasah agar umat Islam mengenal agamanya sejak dini sehingga mereka dapat melaksanakan seluruh ajaran agamanya dengan benar. Dengan harta, wibawa agama terpelihara dan akan lebih kokoh karena terbebas dari meminta bantuan kepada orang-orang yang terkadang malah membenci agama Islam.

\section{E. PEMBAGIAN HARTA}

Para ulama fiqh membagi harta dari berbagai segi :

(1) Dari segi boleh tidaknya harta itu dimanfaatkan menurut syara', harta dibagi kepada dua macam yaitu harta mutaqawwim dan ghair mutaqawwim. ${ }^{11}$ Harta mutaqawwim adalah harta yang boleh dimanfaatkan karena halal zatnya maupun usaha mendapatkannya. Sedangkan harta ghair mutaqawwim adalah harta yang tidak boleh dimanfaatkan zatnya maupun tidak halal usaha mendapatkannya. Dengan pembagian ini maka tidak semua harta boleh dimanfaatkan oleh seorang muslim. Ada beberapa jenis harta yang diharamkan zatnya seperti bangkai, darah, babi, khamar, dan lain-lain yang disebutkan dalam Alquran maupun Hadis Rasulullah saw. Ada juga harta yang haram bukan karena zatnya namun karena cara mendapatkannya tidak dibenarkan syariat. maka ia juga menjadi haram untuk di konsumsi ataupun dimanfaatkan seperti hasil curian, hasil penipuan, hasil dari riba dan lain-lain.

(2) Dari segi dapat tidaknya harta dipindah dari satu tempat ke tempat lain tanpa merusak bentuknya, dibagi menjadi harta 'Uqar dan Manqul. 'Uqar adalah harta atau benda yang tidak dapat bergerak seperti tanah, rumah dan kebun, sedangkan Manqul adalah harta atau benda yang dapat dipindah-pindahkan dari satu tempat ke tempat lain tanpa merusak bentuk aslinya, seperti mobil, pakaian, buku dan lain sebagainya.

(3) Dari segi habis tidaknya harta bila dimanfaatkan, dibagi menjadi harta Istihlaki dan Isti'mali. Istihlaki adalah harta yang jika dimanfaatkan akan segera habis seperti makanan, minuman dan obat-obatan, sedangkan Isti'mali adalah harta yang tetap utuh walau dimanfaatkan berulang kali, seperti rumah, buku, baju dan sebagainya.

\footnotetext{
${ }^{11}$ Ali Haidar, Darr al-Hukkam Syarh Majallah al-Ahkam, Jilid IV, (Beirut: tt, tth), h. 146.
} 
(4) Dari segi ada tidaknya jenis harta tersebut di pasar, dibagi menjadi harta mitsli dan qimi. Harta mitsli adalah harta yang banyak didapati persamaannya di pasar seperti beras, gula, telur dan lain-lain yang biasanya ditimbang, ditakar, diukur, serta dibilang seperti sekilo, seliter, sebuah, semeter, sebutir dan lain sebagainya. Sedangkan harta qimi adalah harta yang tidak ada jenis yang sama dipasar atau ada jenisnya sama dipasar tapi setiap satuannya berbeda besarnya atau kualitasnya seperti pepohonan, perhiasan, emas, berlian dan lain-lain.

(5) Dari segi kepemilikannya, harta dibagi menjadi harta mubah, mamluk dan mahjur. Harta mubah adalah harta yang belum dimiliki siapapun seperti air di sungai, hewan buruan baik di air, di darat maupun yang terbang di udara, seperti ikan, ayam hutan, rusa liar,burung-burungan atau pepohonan di hutan dan tanah yang belum dijamah oleh manusia.

Adapun harta mamluk adalah harta yang sudah dimiliki baik milik pribadi maupun milik bersama atau syarikat. Sedangkan harta mahjur adalah harta yang ada larangan secara syara' untuk memilikinya seperti harta wakaf untuk kepentingan umum, jalan raya atau harta yang ditentukan oleh negara untuk kepentingan umum seperti taman-taman di kota, hutan lindung dan sebagainya.

Dalam memanfaatkan harta, baik untuk dikonsumsi atau manfaat lainnya, maka harta itu harus terlebih dahulu kita miliki atau ada izin maupun kebolehan untuk memanfaatkannya dari orang yang memiliki harta tersebut. Oleh karena itu, pembahasan selanjutnya akan menjelaskan tentang hak milik.

\section{F. PENGERTIAN MILIK}

Ada beberapa pengertian yang dikemukakan oleh para ulama fiqh untuk hak milik, namun jika diamati dengan seksama, secara esensial pengertian milik dapat dikatakan memiliki kesamaan yaitu:

$$
\text { اختصاص بالثئ يمنع الغير منه, ويمكن صاحبه من التصرف فيه إبتداء الا لمانع شرعى. }
$$

"Pengkhususan seseorang terhadap suatu benda yang menghalangi orang selain dia, untuk bertindak hukum terhadap benda tersebut selama tidak ada halangan syara ,", 12

Maksudnya adalah, benda yang dikhususkan kepada seseorang atau yang memilikinya berkuasa penuh terhadap benda tersebut sehingga orang lain tidak boleh bertindak dan memanfaatkannya. Pemilik benda tersebut bebas untuk bertindak hukum terhadap hartanya, seperti menjual, meminjamkan, mewakafkan, dan lain-lain selama tidak ada halangan syara', antara lain apabila pemilik masih anak-anak atau gila atau jauh pailit sehingga dalam hal-hal tertentu mereka tidak dapat bertindak hukum terhadap benda miliknya sendiri. ${ }^{13}$

Kepemilikan terhadap harta sebagaimana telah dijelaskan diatas dalam Islam diarahkan untuk kemashlahatan. Hal ini terkait dengan konsep hak milik yang memberi batasan-batasan bagi pemilik harta, baik dari cara mendapatkannya maupun cara memanfaatkannya. Karena inilah, dalam Islam perlindungan terhadap harta menjadi salah satu tujuan disyariatkannya hukum Islam yang penting dan utama selain perlindungan terhadap agama, jiwa, akal dan kehormatan.

Sudah seharusnya setiap muslim menyadari bahwa hanya Allah yang menciptakan segala sesuatu dan pemilik hakiki dari semua ciptaan yang ada di dunia ini.



${ }^{12}$ Muhammad Abu Zahrah, Al-Milkiyah wa Nazhariyah al-'Aqd fi asy-Syariah al-Islamiyah, (Mesir: Dar al-Fikri al-Arabi, 1992), h. 15-16.

${ }^{13}$ Mustafa Ahmad Zarqa', Al-Madkhal al-Fiqh al- 'Am, Jilid I, (Damaskus: Mathabi' Fata al-Arabi, 1965), h. 241. 
Artinya: kepunyaan Allah-lah segala apa yang ada di langit dan apa yang ada di bumi. dan jika kamu melahirkan apa yang ada di dalam hatimu atau kamu menyembunyikan, niscaya Allah akan membuat perhitungan dengan kamu tentang perbuatanmu itu. Maka Allah mengampuni siapa yang dikehendaki-Nya dan menyiksa siapa yang dikehendaki-Nya; dan Allah Maha Kuasa atas segala sesuatu. (Q.S. al-Baqarah: 284).



Artinya: kepunyaan Allah-lah kerajaan langit dan bumi, dan Allah Maha Kuasa atas segala sesuatu. (Q.S. Ali Imran: 189).

Pemberdayaan manusia atas segala fasilitas kehidupan ini bukan berarti kepemilikan berpindah dari Allah kepada manusia. Oleh sebab itu, dalam pengelolaan terhadap hak milik sementara ini harus tetap berada dalam rambu-rambu yang telah ditentukan syara'.

\section{G. PEMANFAATAN HARTA MILIK}

Pemanfaatan harta yang kita miliki sangat berkaitan erat dengan ketentuan penguasaan harta tersebut. Sejatinya tidak ada kepemilikan mutlak bagi manusia karena semua harta yang ada sebagaiman telah dijelaskan sebelumnya merupakan milik Allah. Untuk itulah, pemanfaatan harta yang telah diamanahkan Allah harus mematuhi peraturan yang ditetapkan Allah melalui Kitab-Nya dan sunnah Rasul-Nya. Kewajiban mengeluarkan zakat, infak dan sedekah, larangan menghamburkan harta dan menyia-nyiakan harta merupakan contoh peraturan yang telah ditetapkan-Nya.

Namun, dari sisi manusia, Islam tetap mengakui kepemilikan mutlak. Kepemilikan berarti berarti berhak untuk melakukan apa saja terhadap harta yang dimiliki selama tidak bertentangan dengan hukum.

Hubungan pemanfaatan dan penguasaan terhadap harta adalah model penguasaan yang bersifat terbatas. Islam membatasi penggunaan harta hanya untuk hal-hal yang bermanfaat dan tidak melanggar hukum seperti berjudi. Kendaraan bermotor atau mobil boleh dimanfaatkan untuk mengantarkan pemilik ke tempat yang boleh dituju. Tentu tidak boleh digunakan untuk mengantar ke tempat maksiat. Pemilik juga dilarang menggunakan kendaraannya dengan kecepatan tinggi atau kebut-kebutan karena hal itu akan membahayakan dirinya dan orang lain.

Jadi, Islam membolehkan pemanfaatan hak milik untuk sesuatu yang mendatangkan maslahat, baik untuk dirinya maupun orang lain. Para ulama fiqh memberi batasan dalam memanfaatkan harta pribadi, antara lain:

(a) Tidak mendatangkan mudharat atau bahaya terhadap dirinya maupun orang lain;

(b) Memberikan sebagian harta pribadi untuk kepentingan masyarakat dan negara seperti mengeluarkan zakat, infak, sedekah, pajak dan lain-lain.

Adapun yang perlu diperhatikan dalam pemanfaatan hak milik terhadap harta ini secara keseluruhan adalah untuk kebahagiaan dan keuntungan di dunia dan akhirat kelak.

\section{H. MACAM-MACAM KEPEMILIKAN}

Para ulama fiqh membagi pemilikan kepada dua bentuk yaitu milk tam (milik sempurna) dan milk naqish (milik tidak sempurna). ${ }^{14}$

Milk Tam adalah kepemilikan terhadap zat atau materi benda sekaligus manfaatnya, dimana si pemilik memiliki seluruh hak yang terkait dengan benda atau harta tersebut. Dengan kata lain, ia berkuasa penuh terhadap hartanya. Milik seperti ini bersifat mutlak, tidak dibatasi dengan waktu dan tidak bisa digugurkan. Contoh: pak Ahmad memiliki sebuah rumah, maka ia berkuasa penuh terhadap rumah itu dan bisa memanfaatkannya secara bebas dan leluasa.

\footnotetext{
${ }^{14}$ Mustafa Ahmad Zarqa', Al-Madkhal, h. 258-259.
} 
Adapun Milk Naqish adalah kepemilikan terhadap zatnya saja atau manfaatnya saja pada harta atau benda. Contoh: pak Ahmad memiliki sebuah rumah, tapi rumah tersebut telah disewa oleh pak Kasim. Dalam hal ini, pak Ahmad hanya memiliki rumah tersebut namun ia tidak memiliki manfaatnya karena manfaat dari rumahnya sudah menjadi milik pak Kasim. Pak Ahmad tidak dapat memanfaatkan rumahnya dan tidak boleh pula bertasharruf terhadapnya, seperti menjualnya atau meminjamkannya kepada orang lain. Pak Ahmad wajib menyerahkan rumah tersebut kepada pak Kasim agar bisa ia manfaatkan. Bila masa sewa telah selesai, maka pak Kasim wajib menyerahkan kembali rumah tersebut kepada pak Ahmad. Sebaliknya, pak Kasim hanya pemilik manfaat rumah yang ia sewa pada pak Ahmad. Pemilikan manfaat dapat terjadi dikarenakan beberapa sebab yaitu, sewa menyewa, pinjam meminjam, wakaf dan wasiat.

\section{CARA BENAR MENDAPATKAN DAN MEMILIKI HARTA}

Sebagaimana telah dijelaskan di atas bahwa pada hakikatnya pemilik mutlak dari harta adalah Allah SWT. Kemudian Allah menyerahkan kepada manusia untuk menguasai harta tersebut melalui izinNya untuk dimanfaatkan, dikelola, diinfakkan sesuai petunjuk syariat. Oleh karena itu, setiap muslim yang telah secara sah memiliki harta tertentu, maka ia berhak memanfaatkan dan mengembangkan hartanya. Hanya saja dalam memanfaatkan dan mengembangkan harta yang dimilikinya tersebut ia tetap terikat dengan ketentuan hukum Islam yang berkaitan dengan hartanya. Ia wajib memnafaatkan hartanya untuk kebutuhan dirinya, keluarganya dan orang yang dibawah tanggung jawabnya, baik untuk kebutuhan dunia maupun agamanya, seperti berzakat bila hartanya telah cukup untuk hal tersebut. Juga wajib pergi menunaikan ibadah haji, membantu para dhuafa' dan untuk kepentingan agama lainnya. Kemudian, ia boleh mengembangkan hartanya namun dengan cara yang diizinkan syariat, seperti melakukan perdagangan, melalui jual beli, syirkah, mudharabah dan lainlain. Ia tidak dibenarkan mengembangkan hartanya melalui praktik riba, perjudian, ataupun cara-cara yang dilarang syariat.

Apa yang terlihat di negara kita dewasa ini, orang-orang sudah tidak lagi peduli dengan ketentuan syariat dalam hal memanfaatkan dan mengembangkan harta. Tujuan untuk menguasai dan memiliki harta sebanyak-banyaknya membuat mereka yang rakus dan tamak telah menghalalkan segala cara. Ketentuan undang-undang negara apalagi syariat, dikesampingkan bahkan dilanggar dan dipijak-pijak. Pihak-pihak yang seharusnya menjaga peraturan tersebut justru ikut merobohkannya.

Bagaimana sebenarnya ketentuan syariat dalam menetapkan kepemilikan terhadap harta ini sudah dikupas sejak lama oleh para ulama. Bagaimana caranya seseorang bisa memiliki harta? Mungkin dengan bertani, bekerja sebagai PNS, sebagai pengacara, sebagai pembantu rumah tangga, sebagai nelayan, berdagang dan lain-lain. Cara mendapatkan harta secara benar oleh para fuqaha disebut dengan asbabul milkiyah, yaitu faktor-faktor yang menjadi sumber kepemilikan terhadap harta.

Ada empat faktor atau sumber kepemilikan sempurna dalam syariat yaitu: ${ }^{15}$

(1) Menguasai harta mubah (Ihraz al-Mubahat).

(2) Akad-akad yang memindahkan kepemilikan (Al-'Uqud an-Naqilah li al-Milkiyah).

(3) Pergantian kepemilikan; warisan dan ganti rugi atas suatu kerusakan atau kebinasaan (Al-Khalafiyah).

(4) Yang lahir dari harta yang telah dimiliki (At-Tawallud min al-Mamluk).

(1) Menguasai Harta Mubah

Sumber kepemilikan pertama adalah menguasai harta mubah. Harta mubah adalah harta yang belum dimiliki siapapun dan tidak ada penghalang dari syariat untuk

\footnotetext{
${ }^{15}$ Wahbah Zuhailiy, al-Fiqh al-Islamiy, Juz IV, h. 2905.
} 
memilikinya. Seperti air di sumbernya, rerumputan liar, pepohonan di hutan, binatang buruan baik darat, laut atau sungai dan tanah yang belum terjamah tangan manusia.

Harta mubah ini mempunyai beberapa karakteristik yaitu: ${ }^{16}$

(a) Ia merupakan asal usul kepemilikan terhadap sesuatu yang belum dimiliki siapapun. Sementara sebab-sebab kepemilikan lainnya seperti jual beli, hibah, warisan dan lainlain semuanya sudah ada pemilik sebelumnya.

(b) Ia merupakan akibat dari perbuatan, bukan perkataan. konsekwensinya, ia dianggap sah dari semua orang walaupun ia termasuk orang yang kelayakannya tidak sempurna seperti anak-anak, orang gila dan mahjur alaihi/bangkrut. Sementara akad boleh jadi tidak sah dari orang-orang tersebut atau tergantung kepada keinginan maupun keizinan orang lain, dan akad termasuk faktor perkataan, bukan perbuatan semata.

Kepemilikan dengan cara menguasai harta mubah harus memenuhi dua syarat yaitu:

Pertama, tidak didahului oleh orang lain, karena siapa saja yang terlebih dahulu menguasai sesuatu maka ia yang lebih berhak memilikinya.

Kedua, ada niat untuk memilikinya. Hal ini sesuai dengan kaidah: الأمور بمقا صدها (Segala urusan tergantung kepada niatnya). ${ }^{17}$

Menguasai harta mubah terbagi kepada empat cara:

(a) Ihyaa al-Mawat, yaitu menghidupkan tanah yang mati. Artinya tanah yang tidak ada pemiliknya dan tidak dimanfaatkan sama sekali, tanah ini diluar perkampungan penduduk dan tidak dimanfaatkan penduduk untuk tempat mencari kayu, menggembalakan ternak atau pembuangan limbah mereka. Mengolah tanah yang kosong ini adalah dengan menjadikannya bisa dimanfaatkan seperti dibersihkan dan ditanami sesuatu, dijadikan sawah atau ladang, dibangun rumah dan dapat pula dibuat sumur.

Membuka tanah baru atau menggarapnya menyebabkan timbulnya hak milik atas tanah yang digarap tersebut. Hal ini berdasarkan hadits berikut ini :



Artinya: Dari Said bin Zaid, dari Nabi saw, beliau bersabda: "Barangsiapa menghidupkan tanah yang mati (membuka tanah baru) maka tanah tersebut jadi miliknya”. (HR. Abu Daud, An-Nasai dan Tirmidzi). ${ }^{18}$

(b) Al-Ishtiyad (berburu), maksudnya adalah berusaha untuk menguasai atau menangkap binatang buruan yang belum dimiliki siapapun. Hal ini dapat dilakukan dengan perbuatan terhadap objek buruan atau dengan cara penguasaan secara hukum seperti melakukan sesuatu yang membuat ikan tidak dapat lari dengan memasang lukah di sungai. Ikan akan masuk ke dalam lukah dan tidak dapat keluar lagi, atau menjerat burung sehingga tidak dapat terbang lagi dan lain sebagainya.

Berburu dihalalkan bagi umat Islam kecuali apabila ia sedang ihram, haji atau umrah, atau buruannya merupakan binatang tanah haram (Mekah dan Madinah). Allah berfirman:



Artinya: mereka menanyakan kepadamu: "Apakah yang Dihalalkan bagi mereka?". Katakanlah: "Dihalalkan bagimu yang baik-baik dan (buruan yang ditangkap) oleh binatang buas yang telah kamu ajar dengan melatih nya untuk

${ }^{16}$ Ibid., h. 2906.

${ }^{17}$ A. Djazuli, Kaidah Fikih, (Jakarta: Kencana, 2007), h. 9.

${ }^{18}$ Muhammad Bin Ismail al-Khalani, Subul as-Salam, Juz. III, (Kairo: Mustafa a-1-Bab al-Hubb, 1980),

h. 83 . 
berburu; kamu mengajarnya menurut apa yang telah diajarkan Allah kepadamu. Maka makanlah dari apa yang ditangkapnya untukmu, dan sebutlah nama Allah atas binatang buas itu (waktu melepaskannya). dan bertakwalah kepada Allah, Sesungguhnya Allah Amat cepat hisab-Nya”.(QS. Al-Maidah: 4). ${ }^{19}$



Artinya: "Dihalalkan bagimu binatang buruan laut dan makanan (yang berasal) dari laut sebagai makanan yang lezat bagimu, dan bagi orang-orang yang dalam perjalanan; dan diharamkan atasmu (menangkap) binatang buruan darat, selama kamu dalam ihram. dan bertakwalah kepada Allah yang kepada-Nyalah kamu akan dikumpulkan”. (QS. Al-Maidah: 96). ${ }^{20}$

Berburu merupakan salah satu sebab timbulnya hak milik atas binatang buruan yang telah ditangkap secara langsung. Adapun buruan yang telah dikuasai secara hukum disyariatkan adanya maksud untuk memiliki. ${ }^{21}$ Siapa yang memasang jaring burungburung laut, lalu ada burung terperangkap dan tersangkut dijaring tersebut, maka burung tersebut menjadi miliknya. Namun jika ia merentangkan jaring tersebut dengan maksud mengeringkan atau menjemurnya, kemudian ada burung yang hinggap ke jaring tersebut dan terperangkap, maka burung tersebut milik siapa saja yang lebih dahulu mengambilnya.

(c) Istila' 'ala al-Kala' wa al-Ajam, yaitu menguasai atau mengambil rerumputan liar dan pepohonan di hutan. Rumput yang tumbuh sendiri boleh dimanfaatkan oleh siapa saja. Pemilik tanah sekalipun tidak boleh melarang orang lain mengambil manfaatnya karena rumput tersebut tetap dalam status ibahah ashliyah (sejak awalanya diperbolehkan), ${ }^{22}$ berdasarkan hadis Rasulullah :

$$
\text { النّاس شركاء فى ثلاثنة: فى الكلإِ و الماء و النّار }
$$

Artinya: "manusia berserikat pada tiga hal yaitu: rumput, air dan api. (HR. Ahmad dan Abu Daud).

Sementara Ajam adalah pohon-pohon besar yang tumbuh dengan sendirinya. Ia termasuk harta mubah jika tumbuh di tanah yang tidak dimiliki siapapun. Setiap orang boleh menguasainya dan mengambil apa yang ia butuhkan. Tidak ada yang berhak melarang dan mencegahnya. Apa yang sudah dikuasainya maka bagian tersebut menjadi miliknya.

Namun demikian, negara berhak untuk membatasi kebolehan tersebut dengan larangan menebang pohon untuk melestarikan hutan dan menjaga lingkungan hidup demi kemashlahatan orang banyak.

Apabila ajam tumbuh di tanah yang telah dimiliki seseorang, maka tidak termasuk harta mubah tetapi menjadi milik si-empunya tanah. Tidak seorangpun boleh mengambil walau sedikit tanpa izin darinya.

(d) Menguasai barang tambang. Barang tambang adalah segala sesuatu yang terdapat di dalam bumi sejak awal penciptaannya seperti emas, perak, tembaga, besi, aluminium, batubara dan sebagainya. Jumhur ulama (Hanafiyah, Syafi'iyah dan Hanabilah) ${ }^{23}$ mengatakan bahwa benda-benda tambang ini mengikut kepada tanahnya. Apabila ia terdapat pada tanah yang telah dimiliki seseorang, maka tambang yang ada didalamnya

\footnotetext{
${ }^{19}$ Departemen Agama, Alquran dan Terjemahnya, h. 107.

${ }^{20}$ Ibid., h. 124.

${ }^{21}$ Wahbah Zuhailiy, al-Fiqh al-Islamiy, Juz IV, h. 2908.

22 Ibid., h. 2909.

${ }^{23}$ Ibn Abidin, Radd al-Muhtar 'ala ad-Darr al-Mukhtar, Jilid I, (Beirut: Dar al-Fikri, tth), h. 61. Lihat pula, Asy-Syirazi, al-Muhazzab fi Fiqh al-Imam Asy-Syafi' $i$, Juz. I, (Beirut: Dar al-Kutub al-Ilmiyah, 1412H), h. 162. Lihat juga, Ibn Qudamah, Al-Maqdasi Al-Mughni, Juz III, (Mesir: Maktabah al-Qahirah, 1968), h. 28.
} 
juga menjadi milik orang tersebut. Bila tambang terdapat didalam tanah milik negara atau sudah dikelola oleh negara maka tambang tersebut milik negara, dan bila tambang tersebut berada didalam tanah yang tidak ada pemiliknya, maka ia termasuk harta mubah dan ia menjadi milik orang yang mendapatkannya. Sementara Malikiyah berpendapat, semua barang tambang adalah milik negara yang digunakan untuk kepentingan orang banyak. $^{24}$

(2) Sumber kepemilikan yang kedua adalah akad-Akad yang memindahkan kepemilikan.

Maksudnya adalah segala akad yang apabila telah dilakukan berakibat berpindahnya hak milik seperti jual beli, hibah, sedekah, infak, wasiat dan sebagainya. Akad-akad inilah sumber utama kepemilikan yang paling umum serta paling banyak dilakukan dalam kehidupan sehari-hari.

Untuk memenuhi kebutuhan hidupnya, manusia melakukan akad yang mencerminkan kegiatan ekonomi sesamanya. Sedangkan sebab kepemilikan yang lain hanya dilakukan sebagian kecil manusia.

Dengan melakukan jual beli maka barang milik penjual akan berpindah menjadi milik pembeli. Sebaliknya, uang pembeli akan berpindah menjadi milik penjual. Begitu juga misalnya dengan sedekah, hak harta yang disedekahkan berpindah dari pemilik pertama menjadi milik yang menerima sedekah.

(3) Sember kepemilikan selanjutnya adalah khalafiyah atau pergantian kepemilikan.

Dalam hal ini, ada dua macam yaitu warisan dan ganti rugi. Dengan meninggalnya seseorang maka seluruh hartanya menjadi milik ahli warisnya secara otomatis. Harta ini disebut warisan.

Kemudian, apabila seseorang merusak harta orang lain maka ia harus menggantinya dan memberikan sebagian harta miliknya kepada orang yang ia rugikan sebagai ganti. Seseorang yang melakukan penganiayaan kepada orang lain juga dapat dikenakan diyat atau ganti rugi kepada orang yang ia aniaya. Demikian pula seseorang yang merugikan hak-hak orang lain, sengaja atau tidak dapat terkena ganti rugi berupa harta yang harus ia milikkan kepada orang lain tersebut.

(4) Tawallud atau yang lahir dari harta yang telah dimiliki

Sumber kepemilikan terakhir adalah tawallud minal mamluk. Maksudnya adalah sesuatu yang muncul atau lahir dari sesuatu yang dimiliki akan menjadi milik dari si pemilik asal. Oleh karena itu maka hasil dari pepohonan berupa buah-buahan atau lainnya, seperti buah durian adalah milik dari orang yang punya pohon durian tersebut. Anak lembu yang lahir adalah milik dari orang yang punya induk lembu tersebut. Bulu dan susu dari kambing biri-biri menjadi milik si empunya kambing biribiri tersebut. Prinsip ini hanya berlaku pada harta benda yang dapat menghasilkan sesuatu yang bisa produktif seperti bertelur, beranak, berkembang biak, berbuah, menghasilkan bulu, susu dan lain sebagainya.

Dari penjelasan di atas dapat dipahami bahwa bila seorang muslim ingin memiliki harta yang halal dan dibenarkan syariat agamanya, hendaklah ia teliti benarbenar apakah harta tersebut berasal dari salah satu sumber kepemilikan ini ? Jika tidak maka waspadalah, jangan sampai ia mengambilnya padahal harta itu tidak halal baginya.

\section{J. KESIMPULAN}

Harta merupakan kebutuhan pokok manusia, baik untuk sandang, pangan maupun tempat tinggal. Dengan harta seseorang menghidupi dirinya, keluarga dan juga agamanya.

\footnotetext{
${ }^{24}$ Ahmad Al-Dardir, Hasyiyah Ad-Daruqy 'Ala Asy-Syarh Al-Kabir, Juz I, (Mesir: Dar. Al-Fikri, tth), h. 486 .
} 
Oleh sebab itu manusia selalu mencarinya dan berusaha untuk mendapatkannya. Harta dapat memberikan kebahagiaan di dunia maupun di akhirat apabila digunakan dalam hal yang benar. Tetapi sebaliknya harta akan menjadi malapetaka bila diperoleh dengan cara yang salah dan digunakan untuk hal-hal yang buruk.

Allah swt menjadikan manusia sebagai penguasa harta di muka bumi untuk dimanfaatkan sesuai aturan yang dibuatNya demi kemaslahatan bersama. Oleh karena itu manusia dibatasi dengan aturan-aturan yang harus dijaga dalam mendapatkan harta, pemanfaatan harta maupun pengembangannya.

Harta yang akan dimanfaatkan seseorang haruslah dimiliki terlebih dahulu atau setidaknya ada izin dari pemiliknya. Islam mengatur rambu-rambu bagaimana cara memperoleh harta dan memilikinya atau biasa disebut oleh para pakar fikih dengan asbabul milkiyah yaitu factor-faktor yang menyebabkan seseorang dinyatakan sah memiliki harta yaitu dengan cara;

1. Ihraz al-Mubahat atau menguasai harta mubah yang terdiri dari menghidupkan tanah mati, berburu, mengambil rerumputan liar dan pepohonan di hutan belantara dan menambang.

2. Melakukan akad-akad yang memindahkan kepemilikan seperti jual beli, hibah, sedekah dan hadiah.

3. Pergantian kepemilikan berupa warisan, diat dan ganti rugi.

4. Pemilikan melalui pengembangbiakan seperti telur dari ayam yang dimiliki, susu dan bulu dari biri-biri yang dimiliki, juga buah-buahan dari pohon yang dimiliki dan lainlain.

5. Di luar ketentuan ini maka seorang muslim tidak dibenarkan untuk mengambil, atau menguasai suatu harta untuk memilikinya. 


\section{DAFTAR PUSTAKA}

Abidin, Ibn. Radd al-Muhtar 'ala ad-Darr al-Mukhtar, Jilid I, Beirut: Dar al-Fikri, tth.

Al-Dardir, Ahmad. Hasyiyah Ad-Daruqy 'Ala Asy-Syarh Al-Kabir, Juz I, Mesir: Dar. AlFikri, tth.

al-Kahlani, Muhammad Bin Ismail. Subul as-Salam, Juz. III, Kairo: Mustafa a-1-Bab alHubb, 1980.

As-Suyuthi, Jalaluddin Abdurrahman. al-Ashbah wa an-Nazhair, Singapura: Sulaiman Mar'i, tth.

Asy-Syirazi, al-Muhazzab fi Fiqh al-Imam Asy-Syafi'i, Juz. I, Beirut: Dar al-Kutub alIlmiyah, 1412H.

Departemen Agama, Alquran dan Terjemahnya, Jakarta: Sabiq, 2009.

Djazuli, A. Kaidah Fikih, Jakarta: Kencana, 2007.

Haidar, Ali. Darr al-Hukkam Syarh Majallah al-Ahkam, Jilid IV, Beirut: tt, tth.

Qudamah, Ibn. Al-Maqdasi Al-Mughni, Juz III, Mesir: Maktabah al-Qahirah, 1968.

Zahrah, Muhammad Abu. Al-Milkiyah wa Nazhariyah al-'Aqd fi asy-Syariah al-Islamiyah, Mesir: Dar al-Fikri al-Arabi, 1992.

Zarqa', Mustafa Ahmad. Al-Madkhal al-Fiqh al-'Am, Jilid I, Damaskus: Mathabi' Fata alArabi, 1965.

Zuhailiy, Wahbah. al-Fiqh al-Islamiy wa Adillatuhu, Juz IV, Damaskus: Dar al-Fikr, 1997. 